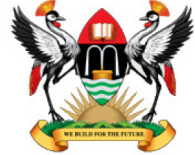

East African School of Higher Education Studies \& Development
Makerere Journal of Higher Education

ISSN: $1816-6822 ; 4(2)(2013) 187-202$

DOI: http://dx.doi.org/10.4314/majohe.v4i2.5

(C) The Author(s) 2012

Reprints \& permission: EASHESD

http://ajol.info/majohe

\title{
Legal Issues in Educational Management in Nigeria
}

\author{
Kayode O. Fayokun ${ }^{1, *}$, Segun O. Adedeji ${ }^{2}$ \\ ${ }^{1}$ Obafemi Awolowo University [*Corresponding author: kfayokun@yahoo.com], \\ ${ }^{2}$ Department of Educational Management, University of Ibadan
}

\begin{abstract}
The interaction of issues of law and schooling are becoming more pronounced by the day as our society continues to witness significant and rapid socio-political and economic changes. In an age that is globally infused with the concern for individual rights, there is of recent an emergence of local court cases as a confrontation of school house authority. In Nigeria, this is a post-1970 phenomenon and discussion on the same in the academic literature is scanty. It is against this background that this paper discusses pertinent legal issues in educational management in the country.
\end{abstract}

Keywords: Legal basis of education; Litigation; Management.

\section{$1 \quad$ Introduction}

The historical domination of religious bodies in education has over the years given way to secularism. In the contemporary Nigeria, education has, until most recently, become a state function. Our post-independence experience (most especially under military rule) has been that the establishment, management and control of schools are an ultimate responsibility of the state. Private sector involvement is now getting more pronounced.

Through the National Universities Commission, National Board for Technical Education, State Primary Education Boards and various school boards, government possesses full power over public schools. Government creates funds and regulates educational institutions through direct, intermediate and local agencies. The ministries of education directly or indirectly provide the finance, curriculum, staffing, management policies and administrative procedures of public schools. Operational decisions, prescription of textbooks, school calendar, hours of school operation and practically every detail of school administration are regulated by government. 
The legal structure of public education in Nigeria involves the three layers of government (i.e. Federal, State and Local Governments). The legislature enacts laws or may delegate its rule-making functions to the administration. An enabling legislation on educational institutions usually prescribes extensive provisions affecting policies, regulations and decisions in schools. Sweeping powers are delegated or conferred on administrators to enact, implement and review the laws under which schools operate and to which they may be called upon to give account.

Executive and adjudicatory control is exercised through government agencies and functionaries. The Minster or Commissioners for education, Governing Councils, Teaching Service Commissions and local schools boards perform such functions of government like the appointment, promotion, discipline and determination of the career of teaching and non-teaching staff of schools.

Judicial control of education in Nigeria through the regular courts is less pronounced. Litigations are few. School laws and regulations are mostly untested in the courts. They are rarely the subjects of judicial interpretation. Where disputes arise on school laws and administration they are frequently on the enforcement of constitutional provisions or breach of rules of procedure. Judicial pronouncements are nevertheless increasingly becoming significant on school matters. Frequently civil cases are now going through the superior courts of record. Usually, trials are commenced at the high court. Dissatisfied litigants appeal from the judgments of the high court to the Court of Appeal from where appeals lie to the Supreme Court which is the apex court.

Once a case is before the court, its role is to interpret the law applicable to the facts. The court carefully refrains from legislating school policies and recasting school legislation. This is especially so where complaints arise from a governing council or schools board's discretion in making rules, policies and procedures for schools, teachers and pupils. As the cases illustrate, the court looks to the reasonableness of the schools board's action and rarely substitutes its wisdom for the boards. Courts are most reluctant to overturn school board's decisions unless they clearly breach the manifest intent of the law or the bounds of reason. The test of "reason", however, has no application where the case clearly involves the denial of or interference with, a constitutional right. The court will insist on following laid-down procedure, due process or the constitutional requirement of fair hearing.

Public schools are creatures of law. Their creation, control and management, and the countless day-to-day decisions are directly or indirectly products of the law. Matters of school finance, teacher-board relations or teaching service commission-employment relations, curriculum, policy making and the effect on teachers, pupils and parents, and a variety of relationships among schools, the community and other bodies all derive from the constitution or enabling 
legislation. Most school problems arise from human interactions that are generated and resolved within the framework of law. The overlapping involvement of the three layers of federal, state and local governments in education creates problems of coordination, uniformity, management and control in Nigeria.

The establishment of institutions for the purposes of University, Professional, Technological or Post-Primary Education is an item in the concurrent legislative list in Part II of the Second Schedule of the 1999 Constitution. What this implies is that both the National Assembly and a State House of Assembly are conferred with powers to establish an institution for the purpose of University, Post-Primary, Technological or Professional education in Nigeria.

The functions of Local Government Councils under the Fourth Schedule of the 1999 Constitution include "the provision and maintenance of primary, adult and vocational education". This implies that Local Government Councils are constitutionally entrusted, through their respective State Governments, with managing the responsibility of primary school education-.

\section{Control and Discipline of Teachers}

The schools management board, which is responsible for the appointment, posting, promotion, transfer and payment of salaries and allowances to teachers, is also charged with the overall disciplinary control of teachers in the service of the board. Without prejudice to the disciplinary power of the board, every State Education Law also provides for the existence of Disciplinary Council whose responsibility is to inquire into allegations of misconduct against a teacher, and determine whether they are serious enough to warrant severe disciplinary action. When an allegation of professional misconduct against a teacher is made, the appropriate education officer will have to inquire into the allegation accordingly. He may take appropriate steps if in the opinion of the board, the alleged misconduct is not proved or is not serious enough to warrant severe disciplinary action against the teacher as the Board may think fit. If the misconduct is such as may warrant severe disciplinary action against the teacher, the Board then has to refer the matter to the Disciplinary Council. Before we proceed to examine the composition of the Council, the principle of fair hearing and "the procedure to be followed by the Disciplinary Council, let us examine some of the disciplinary actions that can be taken against an erring teacher. 


\subsection{Types of Disciplinary Measures}

There are a number of disciplinary measures that can be taken against a teacher for breach of rules of conduct usually described as misconduct. There are many aspects to misconduct. The nature of the disciplinary action to be taken depends on the gravity of the infraction. Disciplinary measures range from warning, interdiction, suspension, demotion, and revocation of certificate, termination to outright dismissal and compulsory retirement.

\subsection{Infractions by Teachers}

In a broader sense, in the schools, the question of infraction by teachers .border mainly on the following areas: 1. Lateness to school and school assemblies; Interval absenteeism from school; Lateness to the classroom for teaching; Failure to prepare lesson notes; Failure to attend staff meetings; Failure to make use of the blackboard in teaching; Examination malpractices (aiding or abetting); Indulging in behaviours that tend to degrade the personality of a student e.g. hair cutting as punishment or cutting skirt to size, etc.; Failure to perform duty as house master - not keeping appropriate house records.,; Indecent dressing; Contributing to the delinquency of a minor; Deliberate negligence of duty; Beating or punishing students in disregard to rules and regulations for punishment; Stealing of school property e.g. stencils, stationery, typewriter, stop watches, microscope, etc.; Fighting with colleague or student; Rudeness or insubordination to the principal or his representative; Corruption or fraudulent practices, e.g. collecting illegal dues from students, embezzlement of school fees, etc.; Failure to keep records of tests and examinations; Failure to mark class register - as class teacher; Aiding students in destabilizing the peace and unity of the school; Forgery of certificates and other personal documents; giving false information; Engaging in activities or crimes that will jeopardize or bring disrepute to the teaching profession or to the school; Drinking alcohol while on duty or getting intoxicated to school; Sleeping while on duty; Smoking while on duty, particularly while teaching; Leaking official and confidential documents to unauthorized persons; Drug addiction; Religious fanaticism and terrorism; Male teacher flogging female students on exposed buttocks; Going home before the normal closing hour; Falsification of accounts; and Forging of transfer certificates or results of students.

\subsection{Professional Misconduct}

Acts or offences specified as professional misconduct by the various Schools Management Boards are varied but also similar in a number of cases and are often listed in the Education Laws or codes of the various States. For example, 
the following acts often specified as amounting to professional misconduct: Conviction for a felony or misdemeanour; Conviction for an offence contrary to the provisions of the Education Law or any regulations made; under the Education Law; In relation to an application for registration as a teacher, knowingly furnishing to the register of teacher's information a fact which is false in a material particular; In relation to an application for employment as a teacher, knowingly making a statement, which is false with the intent to defraud and failing to disclose to the school board any material information within the knowledge of the offender; Having carnal knowledge of a child who is attending an institution at which the offending teacher is a member of staff; Conduct prejudicial to the maintenance of order and discipline in an institution; and Conduct in respect of the staffer pupils in an institution, which is disgraceful or dishonourable.

\subsection{The teacher's right to fair hearing during disciplinary inquiry}

If the allegation of misconduct against a teacher is a serious one that would warrant severe disciplinary action such as demotion, removal of his name from the register of teachers or termination or dismissal, the teacher- against whom the allegation is made must be given a fair hearing. If the principle of fair hearing (substantive and procedural due process) is not adhered to in the proceedings, the court may declare such punishment resulting there from as against the principles of justice and therefore null and void. This is why the laid-down procedure, rules and regulations must be scrupulously followed in the investigation of alleged .misconduct against a teacher, which if established, may lead to severe penalty against him.

The right to fair hearing before severe disciplinary action is taken against a teacher is provided for in most state education laws or codes. It is also one of the fundamental rights provided for in Chapter IV, of the Constitution of the Federal Republic of Nigeria 1999. Section 36 of .the constitution states that:

In the determination of his civil rights and obligations, including any question or determination by or against any government or authority, a person shall be entitled to a fair hearing within a reasonable time by a court or other tribunal established by law and constituted in such manner as to secure its independence and impartiality.

Fair hearing connotes that:

a) A person knows what the allegations against him are

b) What evidence has been given in support of such allegations

c) What statements have been made concerning those allegations

d) Such a person has a fair opportunity to correct and contradict such evidence 
e) The body investigating the charge against such a person must not receive evidence behind his back. The court has a duty once it is seized with the determination of the civil rights and obligations of any persons to be guided by the principles of fair hearing.

The point is further enhanced and made more explicit by Justice Oputa, of the Supreme Court when he wrote as follows: "It is my humble view that fair hearing implies much more than hearing the appellants testifying before the Disciplinary investigation panel, it implies much more than summoning the appellants before the panel; it implies more than other staff or student (or parents) testifying before the Panel behind the backs of the appellants; it implies much more than the appellants being given chance to explain his own side of the story. To constitute a fair hearing, whether it is before the regular courts or before Tribunals and Boards of inquiry, the person accused should know what is alleged against him; he should be present when any evidence against him is tendered and he should be given a fair opportunity to correct or contradict such evidence. How else is this done if it were not "by crossexamination?"

Often, the terms due process of law, substantial justice, or natural justice are used synonymously with fair hearing. For example, in the case of Professor' C.A. Onwumechili and the University of Ife v. Miss Olajobi Akintemi and one other, Justice Uche Omo who presided and read the lead judgment, pointed out that the three basic requirements of natural justice are:

(a) The person accused should know the nature of the accusation made against him

(b) Such a person should be given an opportunity to state his case.

(c) The tribunal investigating the charge against such a person must act in good faith.

In Ajayi and Ors. v. Principal, Ijebu-Ode Grammar School, Justice Sofolahan, then of the Ijebu-Ode High Court, pointed out that the principle of "substantial justice" contains two essential elements:

(a) "the rules of audi altram partem", which requires that, both sides must be heard, and

(b) "nemo judex in causa sua" - which stipulates that no man shall be judge in his own causes.

In the light of the foregoing analysis, it is only reasonable that no teacher should be punished for an alleged offence without being given the chance of a fair hearing.

Finally, the relationship between a teacher and his employer has always been treated as a master and servant relations. The underlying principle in a contract 
of service is that the court recognizes the freedom of contract and respect for rule of law.

\section{$3 \quad$ Legality and Judicial Control}

Through enabling statutes, federal and state ministries of Education or other regulatory bodies have become major delegates of power in the control and management of education in Nigeria. Rules and Regulations made and applied by these bodies have the force of law. The rules, which may sometimes come in form of circulars or notices, are, however, expected to be constitutional and reasonable. Moreover, in their application, all school rules are subject to judicial interpretation. However, because of the presumption of authority, school rules are presumed valid or enforceable and treated as enacted law until they are challenged in the courts. Many reasons may be advanced for the dearth of judicial pronouncements on educational management in Nigeria but there is no gain-saying the fact that our educational and judicial systems are still relatively young and the level of ignorance in the society is still high. Therefore, more reliance is placed on precedents from foreign jurisdictions.

Some landmark judgements upholding school rules may be here referred to. In R. v. Newport Justice (Ex-parte Wright), there was a rule in Newport Grammar School (Shrosphire, England) in 1929 that pupils of the school should not smoke within the school premises or in public during term. One afternoon, two boys left school and smoked as they strolled through the streets. They were seen by prefects who reported them to the headmaster and the headmaster decided that they should be caned for breach of school rule. One boy took his punishment "like a man", but the other objected. He said his father had given him permission to smoke, it was no concern of the headmaster whether he did or not, and the headmaster could not make a rule which flouted the father's authority. Moreover, it had happened away from the school premises and after school hours. The headmaster got two masters to hold the boy down and administer the beating. The father thereupon summoned the headmaster before the magistrate, who dismissed the case. On appeal, the Lord Chief Justice said:

"There was at the school a school rule forbidding smoking by pupils at the school during the school term and on the school premises and in public. That was reasonable rule. The boy deliberately broke the rule, being aware of it, such punishment was a reasonable punishment for the breach of the school rule and the father's application to court must be dismissed".

\section{$4 \quad$ Private Sector Involvement in Education}

Government involvement in education has been overbearing and financially burdensome. The multiplicity of organizational structure, bureaucratic 
regulations at the various governmental levels, coupled with the normal red tapism at the local school level, constitute serious problems and manifest barriers to efficient education. Thus, there is wisdom in encouraging private sector participation in education and reducing the monopoly or overbearing control of government.

The over-regulation and overbearing influence of government in education has taken its toll on educational development in Nigeria. The blanket prohibition of private sector involvement has been the anti-climax of literacy and educational growth.

The purported abolition of private primary education by the Lagos State Government in 1980 was the cause of litigation in the case of Archbishop Anthony Olubunmi Okogie \& Others v. Attorney General of Lagos State. On the 26th March 1980, the Lagos State Government issued a circular letter abolishing private primary schools in Lagos State. The plaintiff, a trustee of Roman Catholic Schools applied under Section 259 of the 1979 Constitution for reference to the Court of Appeal on the following substantial questions of law:

1. Whether or not the provision of educational service by a private citizen or organization comes under the classes of economic activities outside the major sector of the economy in which every citizen of Nigeria is entitled..."

2. By section 18(1) of the Constitution of the Federal Republic of Nigeria, government shall direct its policy towards ensuring that there are equal and adequate educational opportunities at all levels. Is this not an obligation placed on the government of the state to provide equal and adequate educational facilities in all areas within its jurisdiction, rather than preventing or restricting other persons or organization from providing similar or different educational facilities at their own expense?

It was held that the establishment and running of primary and secondary schools by government is a social service but if undertaken by a private citizen could be an economic activity. In our system, there is mutual and co-existing relationship and no legislation in implementing the educational objectives in section 18 of the constitution can override the provisions of Fundamental Rights enshrined in Chapter IV of the 1979 Constitution.

Also in the case of Attorney General oflmo State v. Dr. Basil Ukaegbu, the plaintiff, a proprietor challenged the provisions of the Private Universities Abolition and Prohibition Decree (No. 19) of 1984 which abolished and closed down all existing private Universities in the country. It was held that the Decree was a contravention of constitutional provisions which encourage private participation in economic activities and protect private property interests. 


\section{$5 \quad$ Fundamental Rights}

The following fundamental rights are entrenched in Chapter IV of the Constitution of the Federal Republic of Nigeria 1999; i.e. the:

a) Right to life;

b) Right to dignity of Human Person;

c) Right to Personal liberty;

d) Right to Fair Hearing;

e) Right to private and family life;

f) Right to freedom of thought, conscience and religion;

g) Right to freedom of expression and the press;

h) Right to peaceful assembly and association;

i) Right to freedom of movement;

j) Right to freedom from discrimination;

k) Right to acquire and property; and

l) Right against the compulsory deprivation of property.

These rights are spelt out in sections 33-44 and are the inalienable rights of every citizen of Nigeria. Infringements fundamental rights are very serious constitutional breaches which are not to be treated causally at all. In disputes between citizens or between the government and a citizen, the court stands to protect the provisions of the constitution and preserve the rights of the citizens.

The first of the fundamental rights is the right to life. Every person has a right to life and no one shall be deprived intentionally of his life, save in execution of the sentence of a court in respect of a criminal offence of which he has been found guilty in Nigeria.

Secondly, every individual is entitled to respect for the dignity of his person and accordingly, no person shall be subjected to torture or to inhuman or degrading treatment. Recently, the Lagos State Government beamed its searchlight on the activities of private secondary schools where "virginity tests" have been conducted on new entrants. It was found that the authorities of Beacon International school Amuwo Odofin, Lagos State were conducting "virginity tests" on female pupils under the pretext of ethical sex examination. It was alleged that the school authorities invited a medical doctor to conduct "virginity tests" on the girls and also to find out if any of the boys were infected with Sexually Transmitted Diseases (STDs). It was not clear whether the medical doctor used gloves or bare hands when conducting the medical examination. The prior consent of the parents of such pupils was not sought and it was not clear which purpose the tests were actually supposed to serve as a result. The press blew the incident open and has taken the lead of sensitizing 
the public to the danger of what was termed an invasion of the rights of the pupils to privacy and dignity of their human persons.

There are not as many landmark court decisions relating to education in Nigeria as in Britain or America. This is partly due to the more checkered constitutional history existing in the former's jurisdictions. A cursory look at the constitution of the United States, however, reveal a lot of similarities between the U.S. and Nigerian constitutions with respect to the provisions of fundamental right's" and entrenched freedom of citizens. In the American case of West Virginia State Board of Education v. Barnette, it was held that a compulsory or forced participation in flag salute and recitation of pledge is unconstitutional. Similarly, it has been held that forced religious prayers in public schools conflict with the free exercise of religion clause in the constitution.

The United States District Court in the case of Bray v. Lee held that the use of admission standards and quotas favouring male applicants were unconstitutional. The plaintiffs who were girls who took the same admission examination with many others challenged the admission standard adopted by the Bolton Latin school, alleging that the defendants illegally discriminated against them on the basis of their sex. A girl who took the examination was required to score higher than a boy in order or gain admission. This was because of the disparity in the sitting capacity of the school building. The Bolton school department, in evaluating the results of examinations made a determination of how many seats were available in the boys building and in the girls building. Thus determined, the cut-off mark for girls was higher because of the lesser number of seats available. On the basis of the foregoing, the court decided that the use of separate and different standards to evaluate the examination results to determine the admissibility of boys and girls to the Bolton Latin Schools constitute a violation of the Equal Protection clauses of the fourteenth amendment of the American Constitution, the plain effect of which is to prohibit prejudicial disparities before the law.

It has been said that Bray's case is of particular interest in Nigeria because of the debate on the constitutionality of differential score in admission process of candidates seeking admission to Nigerian Universities through the Joint Admission Matriculation Board and the quota system adopted for Federal (unity) secondary schools. The basis of the admission quota was challenged in Badejo v. Federal Minister of Education. The applicant was a pupil in primary six at the University of Lagos Staff School, Akoka, Yaba, Lagos. Her state of origin is Ogun. She sat for the common entrance examination for admission into Federal; Government Colleges in 1988. When letters of invitation were issued to certain candidates for interview, the applicant was not invited. The defendants published in a national daily that their admission criteria was based on merit, state quota and environmental quota. As a result of this policy the cut- 
off marks differed from state to state and from boy to girl. In respect of Ogun State the purported cut-off marks for boys and girls were 302 and 296 respectively. The applicant scored 293 (i.e. 73\%). From the results pasted on the applicant's notice board it was obvious that some candidates from the same school as the applicant who scored less than the applicant were invited for interview because their states of origin were different from that of the applicant. The list showed that a boy from Kano state and a girl from Benue state who scored 234 which was $58.5 \%$ were invited for interview. Many other candidates who scored between 37.75 and $57.25 \%$ and whose states of origin were Kano and Sokoto were also invited for the same interview. The applicant brought this action seeking for the enforcement of her constitutional and fundamental right against discrimination on the ground of her state of origin. The applicant's application was dismissed at the trial court. On appeal, the Court of Appeal set the ruling of the trial court aside. However, as the matter complained of in the appeal had been overtaken by events and there was nothing more to be remitted to the lower court for further action, the action in the lower court was struck out.

In the celebrated case of Regents of the University of California v. Bakke, Allan Paul Bakke, a white male applicant to the medical school of the University of California at Davis challenged the special admission quota programme of the University which favoured black applicants on the ground that it denied him equal protection of the law by discriminating against him because of his race. It was held that the admission quota for "disadvantaged" students conflicts with the right to freedom from discrimination and the right to equality of rights and opportunities before the law. It has since been clarified that this decision does not preclude "special disadvantages" from being taken care of in the selection process but these must be weighted fairly as a part of the criteria for admission.

On the constitutional protection of economic and property rights of the citizens, three Nigerian cases are instructive. In Okogie's Case, the Lagos State government's' purported" abolition of private primary schools was challenged as unconstitutional. It was held that the constitutional provisions supports free enterprises, and Ipso facto allows the plaintiffs in this case to carry on their chosen economic activity. The establishment and operation of primary and secondary schools by the citizens cannot be impeached. Also in the case of Adewole \& Others v. L.K. Jakande Governor of Lagos State it was held that government's abolition of private schools is an infringement of fundamental rights. In Sam Warn Essi v. Mid-Western state, it was held that no interest in any immovable property shall be compulsorily acquired by the governor without the payment of compensation and guiding any person claiming such compensation a right access to the determination of the amount of compensation. 


\section{School Discipline}

The rules and regulations or students discipline made and applied by Federal and State Ministries of Education, schools management boards, Commission, Governing Councils and other regulatory agencies have the force of law. They cannot be impeached unless they infringe on the provisions of the constitution or fail the test of "reasonableness". It is not uncommon for example for school heads to prescribe certain standards of behaviour in dressing, physical appearance, conduct within school precincts, restriction of movement, school opening and closing hours, courtesy, examination regulations, vocational and curricula involvements etc. for pupils. Such regulations are usually subject to the approval of the delegating authority. In some tertiary institutions, students are required to subscribe to a code of conduct under oath as part of their matriculation. Appropriate penalties are also prescribed for students' misconducts. This punishment may range from warning open rebuke, corporal punishment, and suspension from classroom, rustication and expansion. The more serious punishment is carried out at the outcome of a disciplinary process and with the approval of the appropriate regulatory bodies. It is pertinent to emphasize at all times that rule-making powers in the management of education are exercised mostly under delegation. Thus, they are subject to judicial review.

School disciplinary measures are often subjected to judicial scrutiny on both substantive and procedural grounds of law.

Some- of the legal principles employed to test the validity of a disciplinary measure are:

i) Constitutional appropriateness (.e.g. whether it infringes on fundamental rights or any other enshrined provision of the constitution); ii) The doctrine of ultra vires (e.g. whether it conflicts with an overriding legislative enactment or can be struck down on the ground of "ambiguity", "vagueness" or "unreasonableness"); iii) Compliance with the principles of natural justice (i.e. whether the disciplinary process complies with the twin principles of nemo Judex in causa sua which means no man shall be a judge in his own cause and audialterem partem which require the other side to be heard.

One of the tested areas is the issue of "dress code" adopted in schools. A case in point is that of Jackson v. Dorrier. It involved the subject of long hair worn by teenage male high school students in some American schools. In 1961, the metropolitan Board of Education of Nashville and Davidson country Tennessee adopted a regulation as follows:

"Pupils shall observe modesty, appropriateness, and neatness in clothing and personal appearance. A student is not appropriately dressed if he is a disturbing influence in class or school because of his mode of dress. The principal may suspend a student who does not meet this requirement". Under this regulation, 
the students at Donnellson High School were told, as to hair on male students, that hair in the front may not come below the eyebrows, ears must show clear of hair and hair in the back is to be tapered and not be long enough to turn up.

Two male students, Michael Jackson and Barry Steven Barnes, who were members of a combo bank known as "The Purple Haze" permitted their hair to grow longer than prescribed by school officials and for earning moustaches and abroad. After Conferences with the students and their parents, the students were suspended by the principal and sent home for violation of the regulation after additional conferences and hearing was conducted before the Board of Education. The Board sustained the action of the principal. The students brought the action asking the court to guarantee their constitutional right. There was evidence by the school faculty that the wearing of excessively long hair by the said students actually disrupted classroom atmosphere and decorum, caused disturbances and distractions among other students and interfered with the educational process. It was held that the school regulation had a real and reasonable connection with the successful operation of the educational system and with the maintenance of school discipline. It was held further that the responsibility of maintaining proper standards of decorum and discipline and a wholesome academic environment at Donaldson High School is not vested in the courts but in the principal and faculty of the school.

Similarly, in the case of Spiers v. Warrington Corporation, a 13-year-old girl named Eva Spiers was a pupil at a secondary school in Warrington and turned up at school in clothing which the headmistress considered unsuitable. She came, in fact, in Jeans.

There was a school rule relating to the suitability of clothing in the school. The mother's excuse was that the girl had two bouts of rheumatic fever. She had been advised by a doctor that the girl's kidney should be kept warm, and believed that Jeans keep kidneys Warmer than skirts. The headmistress there upon asked the mother to produce a medical certificate to this effect. No such certificate was forthcoming, and the headmistress asked her repeatedly. Then, she decided to take a well charged but fairly exceptional course. Every time Eva came to school in slacks, the headmistress said to her in effect, "Now run along home dear and come back properly dressed. As soon as you do, you can come into school".

But Eva stayed at home for the morning and arrived at school again in the afternoon. The same conversation would take place and Eva would return the next morning. This went on for some months until the country Borough of Warrington decided to prosecute the father for failing to send his child to school as was his duty. The magistrates found him guilty and fined him. Mr. Spies appealed, maintaining that the magistrates were wrong in law, that he had sent his child to school; and that it was the perversity of the headmistress who 
was preventing Eva from receiving her education, the education to which she was entitled.

Therefore, the conviction was quashed. But on further appeal by the local education authority, the court of the Queen's Bench Division considered the clause in the Articles of Government which said:

"The" headmistress shall control the internal organization, management and discipline of the school" Lord Chief Justice Goddard held,

"The headmistress obviously has the right and power to prescribe the discipline for the school...There must be somebody to keep discipline, and of course is the Headmistress"

In other words, the school rule relating to dress was part of the law of the land and justifiable before the courts. The object of the suit in Flory v. Smith was to test the legality of a rule promulgated by the School Board of Gloucester country. The rule provided that "Leaving the Campus between the hours of 9a.m and 3.35p.m is strictly prohibited unless students are accompanied by a teacher".

The litigant (a parent) sought to restrain the principal of the school from prohibiting his children from eating their mid-day meal outside the school premises (either at their parents' home or in the father's hotel) Campbell, J. held inter alia.

"In the conduct of the public schools it is essential that power be vested in some legalized agency in order to maintain discipline and promote efficiency. In considering the exercise of this power, the courts are not concerned with the wisdom or unwisdom of the act done. The only concern of the court is the reasonableness of the regulation promulgated."

For these reasons, the court held that the principal's suspension of the pupils for flouting the restriction rule was in order.

\section{Conclusion and Observations on Educational Reform}

From the foregoing analyses and comments, some implications and observations about social change and educational reform seem plausible.

At the state level, increasing competition for public fund will place education at a serious disadvantage. Although some organized units within the education enterprise appear to be gaining political leverage (generally the teachers' unions), government is decreasingly responsive to increased costs of schooling. Declining pupil enrolments in many states underscores government disincentive to education. The consequence of this condition is reluctance to make any expensive modifications in school programmes, particularly the labour intensive changes demanded or implied by the malpractice cases. Unless we 
find some way to improve public schools' capabilities, the alternative to reduce expectations seems to be predictable failure with predictable parent and pupil alienation, community dissatisfaction, and debilitating conflict within the school community. Any reduction in conflict levels in and about schools seems unlikely over the next few years.

There is little evidence to support the notion that, given enough resources, schools can achieve almost any assigned objective, the expansion of school objectives over the past several decades is reflected in curriculum, staffing, facilities, and the social-recreational programmes in most schools. The point is, however, that schools are ill-prepared to deliver all the various "fractional" education expected by the larger society. The ailments of the adult world diverse values, juvenile delinquency unresolved social tensions, economic inequalities, social conflict are very much evident in the school environment and for the most part, schools are no more able to "solve" these problems than are the adults in the larger social order. Although it may be understandable for us to continue assigning social problems to schools (particularly if no option is available). To do so with the knowledge that the problems defy solution or are outside the known capacities of the school is fraudulent folly. The routine public disenchantment coupled with disdain for the school's incapacity to deal with some issues renders even less likely any rational sorting out of the proper and improper school undertakings. Further, the growing alienation and hostility toward school performance delays the needed diagnoses of school dysfunction and encourages the attractive belief that if teachers "tried harder" or were "more dedicated", the problems .would diminish'

Schools generally are creatures of the law and, in many aspects, can be reached through the law. But schools are more than legal instruments for social objectives. The organization of schools reflects social, political, and economic decisions »just as complex in nature as the legal considerations sustaining their operation. Clearly, the law, operating through legislation, government agencies, and the courts, impacts upon schools in significant ways. We should not be surprised at finding legal machinery threaded throughout school matters.

The involvement of law in education is hardly an "intrusion" but rather a proper and predictable relationship. We err, however, in expecting the law to resolve school problems created or promoted by other forces. The law can prohibit immoral or anti-social vices; it cannot produce "good" schooling. The law can discourage ineffective instruction but, as yet, it has no capacity to cause effective teaching. The interdependency of the law and the other fundamental elements in schooling is generally unexamined. We need to study the consequences of court decisions on school operation, procedures, and processes. At this point, for example, the Courts' respect for and protection of students' and teachers' constitutional rights reflect a national priority of human rights over organizational interests. In another perspective the public interest in 
open information expressed through financial disclosure laws for school board members takes priority over the possible exclusion of able citizens from board service. These choices are proper and common in our system of government. We should more clearly explicate such choices to all citizens to the end that we might avoid unproductive 'hassles and devote scarce resources to more effective school decisions at the local, state, and national levels. 